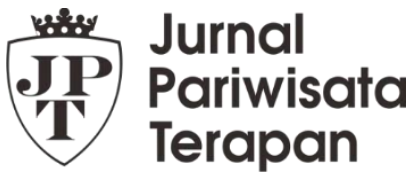

Jurnal Pariwisata Terapan Vol. 4, No. 1, 2020

ISSN-2580-1031 (print) ISSN- 2580-104X (online)

https://jurnal.ugm.ac.id/jpt/article/view/50439

https://doi.org/10.22146/jpt.50439

\title{
Wujud Adaptasi Masyarakat Kalibiru dalam Pengembangan Ekowisata
}

\author{
Kaharuddin $^{1}$, Satyawan Pudyatmoko ${ }^{2}$, Chafid Fandeli ${ }^{3}$, Wisjnu Martani ${ }^{4}$ \\ Affiliation \\ 1,2,3 Departemen Konservasi Sumber Daya Hutan, Fakultas Kehutanan, Universitas Gadjah \\ Mada; ${ }^{4}$ Fakultas Psikologi, Universitas Gadjah Mada
}

\section{Correspondence}

Kaharudin. Departemen Konservasi Sumber Daya Hutan, Fakultas Kehutanan, Universitas Gadjah Mada. Jalan Agro No. 1 Bulaksumur Yogyakarta 55281. Email:

kahar.ugm@gmail.com/kaharudin@ugm.ac.id

\begin{abstract}
Ecotourism development by local communities around the forest has obstacles related the differences between farming and tourism working style. The problem's related the ability of the community to adapt. This study is aimed to describe the types of obstacles, strategies and the form of adaptation of the Kalibiru community in developing ecotourism in the protected forest. Data collection uses in-depth interviews (indept interview), focused interviews, direct observation, and document review. The results showed the ability of the Kalibiru community to adapt of ecotourism. Various obstacles experienced at each stage of tourism development can be overcome through persuasive strategies. The adaptation can be seen in the changes individual behavior, the structure and rules of the HKm institution, and settings of labor and working time at the household level.
\end{abstract}

Keywords: Adaptation; Ecotourism; Local communities.

Article Information

Submitted 8 October 2019 | Revised 21 February 2020 | Accepted 3 September 2020

Recommended Citation: Kaharuddin., Pudyatmoko, S., Fandeli, C., Martani, W. (2020). Wujud Adaptasi Masyarakat Kalibiru dalam Pengembangan Ekowisata. Jurnal Pariwisata Terapan, 4(1), 35-47. https://doi.org/10.22146/jpt.50439 


\section{Pendahuluan}

Ekowisata menjadi tren pengembangan pariwisata di kawasan hutan yang dikelola masyarakat. Ekowisata diyakini mampu dikembangkan dan dapat meningkatkan kesejahteraan masyarakat lokal yang didasarkan pada beberapa hal: berskala kecil sehingga mudah diterima dan diorganisasi masyarakat; mengutamakan partisipasi masyarakat lokal; keuntungan lebih banyak dinikmati masyarakat; pembangkitan apresiasi terhadap kebudayaan lokal dan lingkungan. Kawasan ekowisata yang dikembangkan dengan memperoleh dukungan dari masyarakat memberikan keuntungan pekerjaan dan pendapatan bagi masyarakat, konservasi satwa, ekosistem hutan, penyediaan dana konservasi sekaligus dapat meningkatkan mutu pengalaman wisatawan (Damanik, 2013; Fandeli, 2000; Nasikun, 2000; Wood, 2002; Das, M \& Bani C, 2015). Namun demikian pelibatan masyarakat sekitar hutan dalam mengembangkan ekowisata menghadapi persoalan terkait perbedaan budaya kerja agraris dengan wisata. Tidak sedikit kawasan wisata yang dikembangkan di kawasan alami dikuasai oleh golongan tertentu, seperti temuan Setiawan, B dkk (2017) di Karimunjawa. Hanya golongan masyarakat yang memiliki modal, akses keuangan dan keterampilan mampu terlibat ke sektor pariwisata. Das, M \& Bani C. (2015) mencatat kegagalan ekowisata yang tidak menguntungkan konservasi dan masyarakat lokal seperti kebocoran pendapatan, distribusi pendapatan yang tidak merata, kerawanan lahan dalam skala besar, gangguan terhadap vegetasi dan satwa liar, timbulnya kerawanan sosial di masyarakat, kurangnya kesadaran lingkungan, dan rendahnya kontrol masyarakat. Kegagalan masyarakat dalam pengembangan ekowisata secara umum disebabkan adanya hambatan operasional, struktural budaya dan pendekatan fungsional serta memperlakukan komunitas secara homogen (Blackstock, 2005; Tosun, 2000).

Uraian terkait keberhasilan dan kegagalan masyarakat dalam mengembangkan ekowisata tersebut pada dasarnya terkait dengan kemampuan dan ketidakmampuan masyarakat yang dipandang sebagai masalah adaptasi. Bennet (1976) memandang adaptasi sebagai proses penyesuaian manusia terhadap perubahan lingkungan. Tindakan spesifik dengan tingkat keberhasilan yang dapat diprediksi disebut strategi adaptif. Tindakan tersebut merupakan tindakan inovatif, upaya mengatasi, mencari solusi terhadap masalah yang dihadapi, proses belajar dari situasi yang ada, atau menyesuaikan perilaku dengan realitas. Penelitian ini mengkaji upaya integrasi kegiatan wisata dengan kegiatan produktif tradisional dalam level komunitas/organisasi, rumah tangga dan individu yang terlibat dalam pengelolaan wisata.

Pengelolaan ekowisata yang dikembangkan oleh kelompok petani hutan merupakan fenomena yang belum banyak diteliti, sehingga kasus ekowisata Kalibiru menarik untuk dikaji. Pengembangan ekowisata di kawasan tersebut tidak dapat dipisahkan dari perubahan status kawasan hutan dari hutan produksi menjadi hutan lindung. Kondisi tersebut mendorong Kelompok Tani Hutan Kemasyarakatan (HKm) Mandiri Kalibiru mencari bentuk pemanfaatan yang sesuai dengan fungsi hutan lindung, dan pilihannya adalah ekowisata. Hambatan apa saja yang dihadapi masyarakat Kalibiru dalam mengembangkan ekowisata dan bagaimana strategi mengatasinya, serta bagaimana wujud adaptasinya merupakan pertanyaanpertanyaan yang akan dijawab dalam paper ini. Model Siklus Evolusi Kawasan Wisata (Tourist Area Cycle of Evolution) yang dikembangkan Butler (1980) digunakan sebagai pendekatan untuk menggambarkan dinamika kawasan wisata dan mengidentifikasi faktor-faktor penghambat dan strategi adaptasi pada setiap tahap perkembangan kawasan wisata. McKercher, B (2005), memandang evolusi kawasan wisata dalam model Butler merupakan 
proses perubahan berkelanjutan yang bersifat terbuka dan tak terbatas sebagai hasil interaksi berbagai komponen sistem pariwisata. Wujud respon masyarakat terhadap lingkungan berupa penyesuaian kelembagaan, rumah tangga dan individu (Soekanto, 1970; Cruz, 2005). Respon dalam bentuk mengontrol, mengendalikan dan mengubah faktor-faktor yang berasal dari internal dan eksternal.

Penelitian ini penting dilakukan mengingat semakin berkembangnya wisata yang bersentuhan langsung dengan masyarakat dan kawasan hutan dan dijual dengan label ekowisata. Disisi lain masyarakat sekitar hutan seringkali hanya diletakkan sebagai obyek yang kurang diberi ruang akses untuk terlibat dalam pengelolaan. Pemahaman terhadap adaptasi masyarakat Kalibiru dalam mengembangkan ekowisata dapat menjadi best practice untuk mendorong pengembangan ekowisata berbasis kelompok tani hutan di kawasan hutan yang lain.

\section{Metode Penelitian}

Desain penelitian ini menggunakan strategi penelitian studi kasus dengan unit analisis fenomena perubahan yang terkait perilaku adaptasi masyarakat Kelompok Tani Hutan Kemasyarakatan (KTHKm) Mandiri Kalibiru Kulonprogo dalam pengembangan ekowisata. Proposisi yang disusun untuk membatasi ruang lingkup dan menuntun pencarian dan pengambilan data yang relevan meliputi: identifikasi hambatan dan yang dialami dan strategis yang dikembangkan masyarakat Kalibiru dalam mengembangkan ekowisata. Wujud adaptasi masyarakat Kalibiru dilihat dari bentuk kelembagaan dikembangkan yang terdiri dari struktur organisasi, aturan main pengelolaan dan respon individu dan rumah tangga.

Pengumpalan data dilakukan bulan September 2017 - Juni 2018. Wawancara mendalam (indept interview) bertipe open-ended yang dengan menggunakan multisumber bukti meliputi teknik wawancara mendalam (indept interview), wawancara terfokus, observasi langsung, dan kajian dokumen mana peneliti bertanya ke informan tentang fakta-fakta suatu kasus disamping pandangannya terhadap kasus tersebut. Penentuan informan menggunakan metode snowball dengan melakukan pemilihan informan secara berantai hingga ditemukan informan lanjutan yang layak dijadikan responden. Informan penelitian adalah mereka yang memahami proses dan atau terlibat aktif dalam pengelolaan ekowisata meliputi anggota $\mathrm{HKm}$ pelaku wisata, tokoh pemuda pelaku wisata, dan pendamping. Data-data yang dikumpulkan meliputi penelusuran sejarah perkembangan ekowisata selama rentan waktu 2007 hingga 2018, hambatan yang dihadapi dan strategi mengatasinya dan bentuk wujud perubahan kelembagaan dan perilaku individu. Wawancara terfokus dilakukan dalam waktu yang terbatas untuk mempertajam fakta-fakta tertentu yang diperoleh baik dari informan kunci, observasi maupun dari sumber dokumen. Observasi langsung dilakukan dengan kunjungan lapangan untuk mengamati perilaku pelaku wisata, kondisi organisasi, fasilitas, pelayanan, pertemuan dan informasi lain yang terkait dengan topik penelitian. Observasi dilakukan secara khusus pada waktu tertentu maupun bersamaan dengan kegiatan wawancara.

Penelusuran informasi melalui dokumen-dokumen dari internal organisasi pengelola ekowisata Kalibiru maupun dokumen dari sumber lain, misalnya rencana dan laporan tahunan, dokumen struktur organisasi, laporan hasil penelitian dan artikel-artikel terkait topik penelitian. Dokumen diperlukan untuk mendukung dan menambah bukti dari sumbersumber data yang lain baik sebagai dokumen verifikasi maupun menambah rincian spesifik. Data-data yang sudah diperoleh direduksi dengan memilah-milah data yang relevan dan 
dilakukan pengelompokkan data menjadi beberapa kategori serta menemukan hubungan antara kategori. (Creswell, 2015; Yin, 2015).

\section{Hasil Dan Pembahasan}

\section{Gambaran Lokasi Penelitian}

Destinasi ekowisata Kalibiru yang terletak di kawasan hutan lindung yang dikelola oleh masyarakat Kelompok Tani Hutan Kemasyarakatan (KTHKM) Mandiri terletak di Dusun Kalibiru, Kec. Pengasih, Kab. Kulonprogo, Daerah Istimewa Yogyakarta. HKm Mandiri Kalibiru mendapat Izin Sementara pengelolaan hutan tahun 2003 yang berlaku 5 tahun dan akhir tahun 2007 mendapat ijin tetap atau IUPHKm (Ijin Usaha Pengelolaan Hutan Kemasyarakatan) dari Kementerian Kehutanan selama 35 tahun (Aji dkk, 2015).

Jumlah pengunjung rata-rata selama 2010-2018 sebanyak 158.860 orang pertahun dengan jumlah pengunjung terbanyak tahun 2016 sebanyak 443.070 orang. Perolehan pendapatan rata-rata selama periode tersebut sebesar Rp 1,9 milyar dengan pendapatan tertinggi sebesar Rp. 5,4 milyar yang dicapai tahun 2017 (Kalibiru, 2018). Jumlah penduduk Dusun Kalibiru tahun 2017 tercatat sebanyak 457 jiwa, 147 kepala keluarga, dan anggota KTHKm sebanyak 104 orang. Mata pencaharian kepala keluarga (KK) 70\% sebagai petani dan buruh, 52\% KK berpendidikan SD dan 69\%, dan umur rata-rata KK di atas 50 tahun (Anonim, 2017; Kaharuddin, 2016). Jumlah masyarakat yang terlibat wisata sebanyak 247 orang dan menyerap 85\% keluarga dari Dusun Kalibiru, 46\% anggota kelompok tani HKm Mandiri, $44 \%$ pemuda dan $37 \%$ perempuan. Masyarakat yang terlibat sebagai pelaku wisata umumnya (77\%) berpendidikan sekolah menengah sampai perguruan tinggi (Analisis data survei 2018).

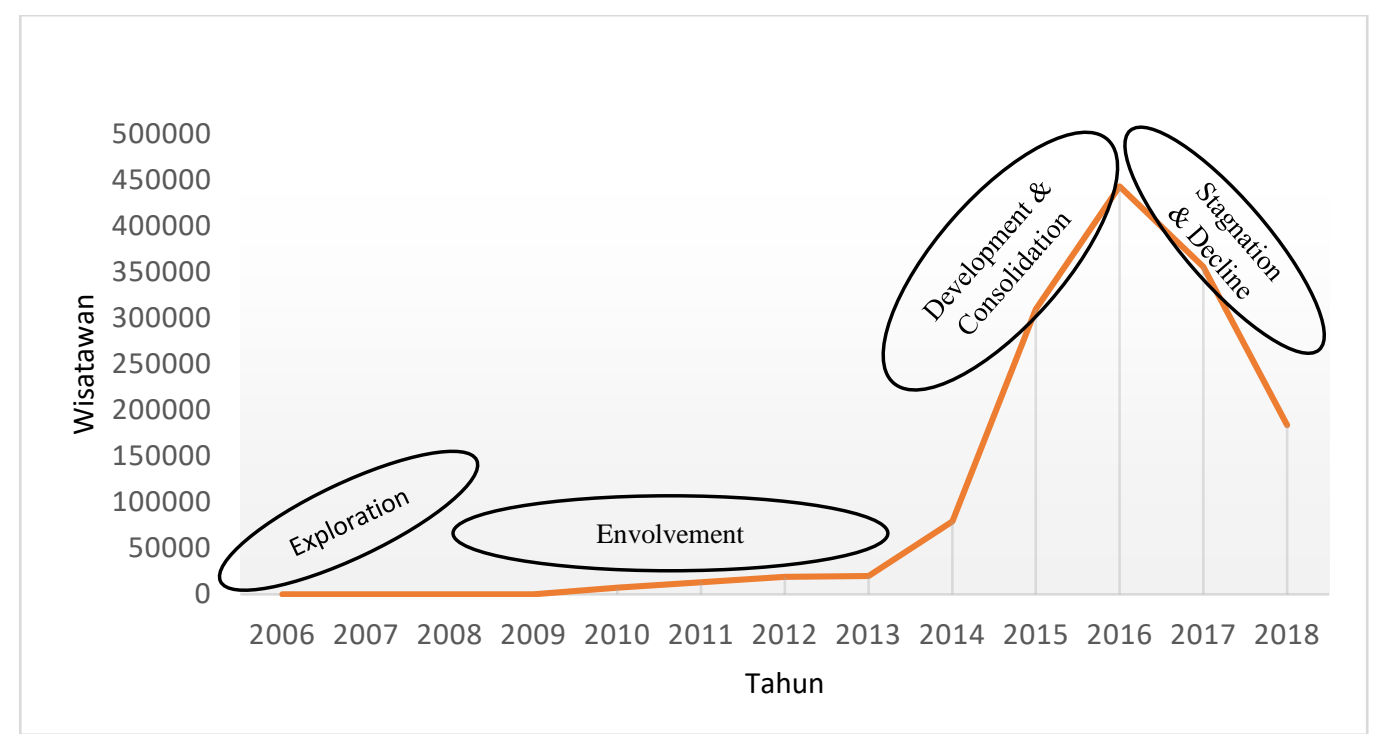

Gambar 1. Siklus Perkembangan Kawasan Ekowisata Kalibiru (Sumber: Adaptasi Model Butler, 2019)

\section{Perkembangan Ekowisata Kalibiru}

Perkembangan ekowisata Kalibiru digambarkan sebelum wisata dikembangkan hingga wisata berkembang pesat. Model Siklus Evolusi Kawasan Wisata (Tourist Area Cycle of Evolution) Butler (1980) digunakan sebagai pendekatan untuk menggambarkan perkembangan tersebut. Model Butler yang terdiri dari beberapa tahapan meliputi: Tahap exploration 
dicirikan dengan jumlah pengunjung sedikit, fasilitas wisata belum ada, kawasan wisata masih alami, pencarian daya tarik wisata. Tahap envolvement: jumlah pengunjung mulai meningkat, penduduk lokal mulai terlibat dalam pelayanan pengunjung, adanya promosi, penyesuaian organisasi, tuntutan kebutuhan sarana dan prasarana serta fasilitas wisata meningkat. Tahap development : segmen pasar sudah terbentuk, keterlibatan pihak luar dalam pembangunan fasilitas dan tenaga kerja, fasilitas wisata sudah dilengkapi, perubahan kondisi fisik, jumlah pengunjung meningkat. Tahap consolidation: pertumbuhan pengunjung mulai menurun, ekonomi daerah digerakkan pariwisata, pemasaran yang luas, muncul ketidakpuasan dari penduduk lokal. Tahap stagnation, jumlah pengunjung puncak tercapai, daya dukung wisata tercapai, munculnya masalah sosial, ekonomi, dan lingkungan, obyek wisata alami tergantikan dari luar, perkembangan daerah sekitar obyek wisata, perubahan kepemilikan lahan. Tahap decline: wisatawan menurun, kawasan wisata tidak mampu bersaing dengan obyek yang baru, fasilitas under use, perubahan fungsi fasilitas, obyek wisata sepi pengunjung. Tahap rejuvenation, perubahan dan penambahan daya tarik, munculnya keunikan obyek, optimalisasi sumberdaya, penambahan fasilitas baru, reorientasi pasar baru. Perkembangan yang terjadi pada setiap obyek wisata berbeda-beda tergantung pada perubahan yang terjadi seperti perubahan kebutuhan pengunjung, fasilitas, atraksi wisata, aksesibilitas, kebijakan pemerintah, dan tingkat persaingan obyek wisata (Butler, 1980, 2011). Tahapan perkembangan kawasan ekowisata Kalibiru diuraikan sebagai berikut.

\section{Tahap Ekploirasi (Exploration)}

Pembangunan wisata Kalibiru tidak diawali oleh adanya embrio kunjungan wisatawan, melainkan disebabkan oleh keterpaksaan. Masyarakat anggota Kelompok Tani HKm yang didampingi LSM mengajukan proses perijinan kelola lahan hutan produksi melalui mekanisme Hutan Kemasyarakatan (HKm). Ditengah proses pengurusan ijin tersebut, terjadi perubahan status hutan dari hutan produksi menjadi hutan lindung. Perubahan tersebut membatasi akses masyarakat sehingga menimbulkan kekecewaan dan kemarahan masyarakat karena harapannya mengelola lahan hutan untuk pertanian secara legal dan mendapatkan hasil kayu kelak tidak mungkin terwujud. Ditengah kondisi tersebut, beberapa tokoh HKm Mandiri berdiskusi dengan aktivitis LSM untuk mencari peluang pemanfaatan yang memungkinkan dilakukan dalam hutan lindung. Dalam Peraturan Pemerintah No. 34 Tahun 2002 tentang tata hutan, pemanfaatan hutan lindung terdiri dari 3 jenis yaitu pemanfaatan kawasan, jasa lingkungan dan pemungutan hasil hutan bukan kayu. Berdasarkan diskusi internal, hanya pemanfaatan jasa lingkungan berupa usaha wisata alam yang dinilai potensial dikembangkan di Kalibiru. Letak geografis hutan lindung Kalibiru yang merupakan upland dari Waduk Sermo menghadirkan pemandangan ke arah waduk Sermo dan pantai selatan yang indah. Namun demikian, ide mengembangkan wisata dinilai oleh banyak anggota $\mathrm{HKm}$ sebagai mimpi yang menganggap daerahnya kurang menarik untuk dikunjungi.

\section{Tahap Keterlibatan (Envolvement)}

Periode ini berlangsung pada tahun 2008-2013 yang merupakan titik awal perkembangan wisata Kalibiru. Perjuangan masyarakat Kalibiru untuk mengembangkan wisata dilakukan bersama-sama dengan aktivis LSM dan 6 kelompok HKm yang ada di Kulonprogo yang tergabung dalam komunitas LINGKAR (Peduli Lingkungan Alam Lestari). Bulan Juni 2008 mereka mengadakan acara 
"Sedekah Bumi" yang dihadiri oleh Bupati Kulonprogo. Kegiatan tersebut dimaksudkan untuk menunjukkan eksistensi HKm Kulonprogo, sekaligus sarana sosialisasi rencana pengembangan wisata alam. Setelah kegiatan tersebut, komunitas LINGKAR mendapat bantuan dana untuk pengembangan wisata yang ditempatkan di kawasan HKm Kalibiru. Pembangunan sarana prasarana wisata dilaksanakan melalui mekanisme swakelola yang melibatkan banyak anggota $\mathrm{HKm}$ dan masyarakat Kalibiru. Langkah awal yang dilakukan untuk mendatangkan wisatawan adalah menjalin kerjasama dengan instansi pemerintah daerah dalam bentuk penyelenggaraan pelatihan-pelatihan dan outbond di Kalibiru. Upaya pembangunan dan promosi wisata terus dilakukan dan mendapat respon baik dari wisatawan meskipun peningkatan jumlah kunjungan masih terbatas. Sadar akan keterbatasan yang dimiliki, pengelola $\mathrm{HKm}$ mengajak beberapa tokoh pemuda (non anggota $\mathrm{HKm}$ ) untuk membantu pengelolaan wisata. Keterlibatan tokoh-tokoh pemuda dalam pengelolaan wisata masih terbatas pada akhir pekan. Kondisi tersebut disebabkan oleh jumlah pengunjung dan pendapatan dari wisata masih kurang untuk dijadikan tumpuan hidup. Jumlah pengunjung rata-rata selama periode tersebut sebanyak 14.745 orang/tahun dengan pendapatan rata-rata Rp. 44.619.237,-/tahun. Keterlibatan masyarakat dalam jumlah banyak pada tahap perkembangan ketika jumlah kunjungan yang meningkat dan membutuhkan karyawan untuk pelayanan.

\section{Tahap Pengembangan (Development) dan Konsolidasi (Consolidation)}

Semangat masyarakat Kalibiru mengembangkan wisata semakin meningkat dengan ditetapkannya HKm Mandiri Kalibiru menjadi Juara 1 nasional Wana Lestari oleh Kementerian Lingkungan Hidup dan Kehutanan. Pengurus diterima Presiden Susilo Bambang Yudoyono di Istana Negara tanggal 17 Agustus 2014 (Konservasi Wiratno, 2017). Kondisi tersebut menarik berbagai kalangan dari instansi pemerintah, organisasi masyarakat, perguruan tinggi dan masyarakat umum berkunjung untuk tujuan studi banding, penelitian dan atau berwisata menikmati atraksi foto selfie. Periode ini menjadi masa kejayaan HKm Mandiri Kalibiru yang ditandai peningkatan jumlah pengunjung dan pendapatan yang mencapai 5 Milyar. Kebutuhan tenaga kerja untuk melayani wisatawan semakin meningkat dan sebagian besar direkrut pemuda dari warga Dusun Kalibiru dan dusun sekitarnyan. Selain itu, periode ini juga menjadi masa konsolidasi antara warga anggota HKm dan warga Dusun non anggota $\mathrm{HKm}$, serta warga sekitar. Konsolidasi juga dilakukan dengan HKm Jaringan LINGKAR untuk mengembangkan obyek wisata yang terjalin dengan Kalibiru. Pembangunan fasilitas dan sarana wisata selama periode ini tidak lagi mengandalkan dana bantuan dari luar tetapi melalui pembiayaan secara mandiri.

\section{Tahap Stagnasi (Stagnation) dan Penurunan (Decline)}

Tahapan ini menunjukkan adanya penurunan jumlah wisatawan sebesar $-34 \%$ selama periode 2017-2018, namun demikian kunjungan wisatawan bulanan tidak menunjukkan perbedaan yang menyolok. Maraknya perkembangan obyek wisata foto selfie di sekitar Kalibiru dan berbagai daerah yang menawarkan beragam model dan nuansa spot foto yang berbeda, menjadikan persaingan semakin berat. Upaya mengembangkan atraksi baru termasuk kerjasama dengan pihak ketiga, kerjasama promosi dengan biro perjalanan nampaknya belum mampu meningkatkan 
kunjungan dan pendapatan diakhir tahun 2018. Ditengah kondisi tersebut, dengan pengalaman, pengetahuan dan jaringan yang dimiliki pengelola senantiasa mencari ide untuk terus berinovasi agar ekowisata di Kalibiru dapat tumbuh kembali.

\section{Hambatan dan Strategi Adaptasi Masyarakat Kalibiru}

Perjalanan ekowisata Kalibiru yang berlangsung selama 10 tahun mengandung banyak hal penting untuk dipahami. Selama kurung waktu tersebut, berbagai hambatan dan tantangan yang dihadapi masyarakat Kalibiru dalam pengembangan ekowisata dari aspek sosial, kapasitas, finansial, dan fisik/geografis. Jenis hambatan dan tantangan tersebut berbeda pada setiap tahapan perkembangan kawasan wisata dan disikapi masyarakat dengan strategi yang berbeda pula. Jenis hambatan dan strategi adaptasi yang dipilih masyarakat Kalibiru diuraikan sebagai berikut.

\section{Aspek Sosial}

Permasalahan sosial yang dihadapi dalam pengembangan wisata Kalibiru (masa awal, ketika berkembang dan periode penurunan) terkait dengan dukungan, pelibatan masyarakat dan tanggung jawab sosial. Kekecewaan dan kemarahan masyarakat atas perubahan status hutan menjadi hutan lindung yang membatasi ruang aksesnya berdampak pada beberapa hal. Hubungan internal $\mathrm{HKm}$ menjadi kurang harmonis dan beberapa masyarakat berniat untuk kembali merambah hutan, sikap apriori dan respon yang kurang terhadap ide pengembangan wisata. Kondisi tersebut diatasi dengan membangun kembali semangat kolektif anggota $\mathrm{HKm}$ dengan menyelenggarakan acara Sedekah Bumi, pengajuan bantuan ternak dan kompensasi untuk tetap bertani di lahan hutan lindung serta bantuan bibit tanaman multi purposes tree species (MPTS) ke Dinas Kehutanan. Ditengah implementasi program tersebut, dilakukan sosialisai pembangunan wisata melalui pihak ketiga. Ketika wisata mulai berkembang, pengurus HKm merasa tidak memiliki kemampuan untuk mengelola wisata, sehingga dilakukan pelibatan tokoh-tokoh pemuda dan pemberian bantuan pendanaan kepada beberapa anggota $\mathrm{HKm}$ yang berkenan membangun warung secara swadana merupakan upaya lain yang dilakukan pengurus HKm.

Tahun 2014-2016 merupakan titik balik perkembangan wisata Kalibiru ketika jumlah pengunjung dan pendapatan meningkat pesat. Kondisi tersebut menjadi magnet besar bagi masyarakat untuk terlibat dalam pengelolaan wisata, namun tidak memungkinkan untuk mengakomodasi seluruhnya. Kondisinya diatasi dengan membuat aturan perekrutan karyawan yang mengutamakan anggota keluarga $\mathrm{HKm}$ dan masyarakat Kalibiru. Sejalan perkembangan ekowisata yang terus meningkat muncul kecemburuan dari anggota HKm dan anggota masyarakat Kalibiru yang tidak terlibat dalam pengelolaan wisata. Pengelola menyadari pentingnya hal tersebut untuk diselesaikan karena dapat mengganggu kinerja pengelolaan. Melalui mekanisme musyawarah, HKm meluncurkan pendanaan perlindungan hutan yang diberikan kepada seluruh anggota $\mathrm{HKm}$ setiap 4 bulan sekali sesuai masa panen tanaman. Bagi masyarakat yang kurang mampu disediakan bantuan sosial berupa bantuan tunjangan hari raya, bedah rumah, disamping itu, pembangunan sarana dan fasilitas umum Kampung (rehab masjid, rehab pagar makam, pembangunan gedung TPA, perbaikan jalan kampung) yang dapat dinikmati oleh seluruh warga Kalibiru. 
Hambatan pengelolaan wisata juga berasal dari daerah sekitarnya yang dilalui wisatawan menuju Kalibiru dalam berbagai bentuk seperti adanya cegatan wisatawan, protes akibat jalan menjadi rusak dan berdebu. Hal tersebut diselesaikan dengan memberikan bantuan kepada dusun sekitar berupa bantuan sarana ibadah, perbaikan dan pemeliharaan jalan yang dilewati wisatawan, perekrutan warga sekitar Kalibiru sebagai karyawan wisata. Disamping pendekatan kekeluargaan juga dilakukan koordinasi dengan kepolisian setempat untuk membantu menangani halhal yang menggangu lalu lintas dan keamanan wisatawan. Selain itu, ada "tuntutan" dari Jaringan HKm LINGKAR yang terkait dengan sharing untuk pengembangan wisata di HKm lain sebagaimana kesepakatan awal. Kondisi tersebut diselesaikan melalui musyawarah dalam pertemuan rutin dan pemberian sharing pendanaan yang disesuaikan pendapatan Kalibiru.

Setelah pengunjung dan pendapatan mulai menurun tahun 2017 permasalahan yang dihadapi terkait dengan beban sosial yang menyangkut nasib karyawan dan masyarakat yang selama ini menggantungkan hidupnya di wisata. Upaya mempertahankan kunjungan dengan mengembangkan atraksi baru dan kerjasama dengan biro travel, pelaku wisata dari luar nampaknya belum mampu mengatasi hal tersebut. Tindakan efisiensi dilakukan dengan mengurangi beban cost antara lain pengurangan jam kerja karyawan kontrak.

\section{Aspek Kapasitas SDM}

Keterbatasan kapasitas SDM untuk mengembangkan wisata telah disadari oleh masyarakat anggota HKm sejak awal. Keterbatasan yang dirasakan terkait dengan ketidakmampuan menyusun rencana dan desain pembangunan, ketidakmampuan dalam pencarian dana, dan mendatangkan wisata. Kondisi tersebut disikapi melalui bantuan dan pendampingan dari aktivis LSM. Ketika kunjungan sudah banyak dan meningkat pesat pada tahun 2010-2016, hambatan yang dialami terkait teknis pelayanan dan keamanan pengunjung, waktu dan irama kerja (kedisiplinan), teknis fotografi, bahasa, percaya diri. Penyusunan aturan main (SOP) dan pelatihan penggunaan standar keamanan fasilitas permainan dan panggung foto, kedisiplinan kerja berbasis teknologi finger print. Keterbatasan dalam skill fotografi dan bahasa diatasi dengan merekrut karyawan yang memiliki keahlian tersebut dan adanya maganisasi melalui proses learning by doing. Bekerja dengan sistem berkelompok menjadi upaya lain untuk mengatasi keterbatasan yang karyawan dapat saling melengkapi kekurangan, sekaligus menjadi sarana belajar bersama. Keterbatasan inovasi untuk menghadirkan atraksi-atraksi yang menarik dan menguntungkan dilakukan melalui studi banding ke beberapa obyek wisata. Ketika pengunjung mulai menurun tahun 2017, beberapa masyarakat yang memiliki usaha melakukan penyesuaian penggajian karyawan dan jam kerja dengan membuka usahanya pada hari libur dan weekend saja.

\section{Aspek Finansial}

Keterbatasan finansial sangat dirasakan masyarakat anggota $\mathrm{HKm}$ pada saat awal pembangunan wisata. Kehidupan masyarakat sebagai petani dengan kondisi perekonomian yang terbatas merupakan kenyataan yang tidak memungkinkan 
pembangunan ekowisata dilakukan secara swadana. Kerjasama dengan aktivis LSM, HKm berhasil mendapat pendanaan tahun 2008, 2012, 2013 dari berbagai sumber yang dimanfaatkan untuk pembangunan sarana dan fasilitas wisata. Periode tahun 2015-2018 ketika pengunjung dan pendapatan obyek wisata sudah meningkat, pendanaan pembangunan dan pengelolaan ekowisata diselesaikan secara swadana. Kendati demikian, beberapa masyarakat terlibat dalam bidang usaha wisata memiliki keterbatasan pendanaan dan diatasi melalui pinjaman dana ke keluarga, Bank dan dari $\mathrm{HKm}$ dengan jumlah terbatas. Manajemen keuangan individu anggota $\mathrm{HKm}$ dan karyawan wisata yang kurang baik turut menjadi perhatian pengelola $\mathrm{HKm}$. Kerjasama HKm Mandiri dengan Bank BRI dalam mengelola gaji karyawan berdampak positif dalam pengelolaan keuangan karyawan. Anggota $\mathrm{HKm}$ Mandiri dan karyawan wisata mendapat kemudahan pinjaman dari Bank tanpa agunan tapi melalui persetujuan pengurus HKm Mandiri. Disamping itu, pihak Bank juga menyediakan fasilitas ATM di kawasan wisata Kalibiru untuk memberikan kemudahan bagi karyawan, anggota HKm masyarakat maupun wisatawan yang membutuhkan uang dengan cepat.

\section{Aspek Fisik}

Kawasan wisata Kalibiru terletak di puncak salah satu perbukitan yang merupakan upland waduk Sermo. Topografi kawasan yang berbukit dengan terbatasnya ruang yang datar atau landai untuk membangun berbagai sarana dan fasilitas wisata, sehingga membutuhkan desain dan teknik tertentu dalam pembangunannya. Penempatan bangunan dilakukan secara berderet di sepanjang igir bukit sehingga memberikan ruang pandang yang indah ke waduk Sermo dan pemandangan lanskap ke beberapa sisi. Sarana dan fasilitas dibangun dengan konstruksi semi alami agar keawetannya terjamin dan kesan alami dan persyaratan fasilitas wisata di kawasan hutan terpenuhi. Topografi lahan yang berbukit menyebabkan jalur akses dalam kawasan cukup menantang, terutama jalan dari lokasi parkir sampai masuk pintu/loket yang langsung menanjak. Sementara jalan setapak untuk mengakses beberapa spot foto dan atraksi kondisinya naik turun menjadi kendala tersendiri bagi wisatawan tertentu. Guna memberikan kenyamanan bagi wisatawan, pengelola menyediakan beberapa shelter/bangku dan warung-warung di bangun sepanjang jalur sirkulasi yang dapat dimanfaatkan wisatawan untuk beristirahat dan menikmati keindahan alam Kalibiru. Di samping itu, pengelola juga menggeser posisi pintu masuk/loket agak ke dalam mendekati atraksi yang lokasinya relatif datar dan wisatawan bisa menggunakan kendaraan sampai mendekati loket.

Akses jalan menuju kawasan wisata Kalibiru dapat dijangkau melalui 2 arah, yaitu akses jalan dari Kota Wates - Waduk Sermo - Kalibiru, dan akses jalan SentoloPengasih-Clereng-Kalibiru. Kedua jalur akses tersebut kondisinya menanjak, sempit dan berkelok khususnya sekitar 2 km ketika mendekati kawasan wisata Kalibiru. Akses jalan ini menjadi masalah ketika peak season dan bagi mobil yang tidak prima atau sopir yang kurang terbiasa dengan medan tanjakan yang berat. Upaya yang dilakukan untuk mengatasi hal tersebut dengan menempatkan petugas pengatur lalu lintas (dinamakan marshal) sepanjang jalan sekitar $1 \mathrm{~km}$ sebelum kawasan wisata Kalibiru. Setiap marshal dilengkapi dengan handy talky untuk memudakan komunikasi dan koordinasi dalam mengatur arus lalu lintas wisatawan. Di samping 
itu, HKm Mandiri Kalibiru juga menyediakan kendaraan rescue yang standby setiap hari di kawasan wisata.

Secara umum strategi yang dikembangkan masyarakat Kalibiru dalam mengatasi kendala yang dihadapi oleh Kotler (1971) disebut sebagai strategi persuasif. Tindakan persuasif yang dilakukan meliputi menumbuhkan semangat kolektif, sosialisasi rencana melalui pihak ketiga, pelibatan tokoh-tokoh masyarakat, pemuda dan warga Kalibiru secara luas, program bantuan sosial dan konservasi hutan.

\section{Sub Pembahasan}

Dinamika perkembangan kawasan wisata Kalibiru sebagaimana tercermin pada uraian poin B dan $\mathrm{C}$ di atas menunjukkan kemampuan masyarakat Kalibiru beradaptasi dengan ekowisata. Ciri khas yang menonjol dari model siklus wisata Kalibiru terletak pada pemberdayaan masyarakat petani hutan dalam proses pembangunan dan pengelolaan wisata. Soetomo (2015) menyebutkan unsur pemberdayaan terdiri dari kewenangan dan kemampuan masyarakat. Masyarakat membutuhkan kemampuan adaptasi untuk mengaktualisasikan kewenangan yang dimiliki dalam melakukan pembangunan ekowisata. Proses pembangunan ekowisata Kalibiru mampu merubah sikap dan pola pikir masyarakat anggota HKm tentang ekowisata yang awalnya tidak mendukung, under estimate. Pengunjung dan pendapatan $\mathrm{HKm}$ yang terus meningkat merubah sikap dan pola pikir masyarakat menjadi dukungan yang tinggi untuk terlibat dalam pengelolaan wisata dan menyakini ekowisata mampu meningkatkan kesejahteran masyarakat. Raihan pendapatan yang diterima masyarakat jauh melebih pendapatan dari aktivitas pertanian dalam kawasan hutan. Pendapatan rata-rata karyawan wisata sebesar Rp. 2.500.000,-/bulan. Selain itu, proses pengembangan ekowisata di Kalibiru juga menggeser proses pengambilan keputusan dan penyusunan rencana yang awalnya banyak dilakukan oleh pendamping. Seiring perkembangan wisata dengan segala pengalaman dimiliki masyarakat melalui proses belajar, pengurus HKm mampu melakukan kewenangan tersebut dengan baik.

Keberhasilan pembangunan ekowisata Kalibiru tidak hanya terletak pada kewenangan yang dimiliki masyarakat tetapi juga pada kapasitas adaptasinya. Adaptasi masyarakat Kalibiru dalam pengembangan ekowisata diwujudkan dalam bentuk penyesuaian kelembagaan, individu dan rumah tangga. Adaptasi kelembagaan berupa penyesuaian struktur dan aturan main pengelolaan (Soekanto, 1970). Penyesuain struktur lembaga HKm Mandiri terjadi melalui pelibatan orang-orang non $\mathrm{HKm}$ khususnya pemuda menjadi pengelola wisata. Bidang wisata alam merupakan salah satu unit usaha dalam lembaga $\mathrm{HKm}$ yang bertanggung jawab dalam operasional wisata, sementara kegiatan perencanaan dan pengembangan program, penyusunan kebijakan dan pendanaan wisata menjadi tanggung jawab pengurus $\mathrm{HKm}$. Perubahan juga terjadi dalam susunan pengurus organisasi $\mathrm{HKm}$ Mandiri yang dulunya diisi sepenuhnya oleh anggota $\mathrm{HKm}$, mengalami penyesuaian dengan direkrutnya pemuda untuk mengisi posisi sekretaris. Penyesuaian kelembagaan juga dilakukan dalam bentuk penyusunan aturan main pengelolaan wisata untuk mengatasi hambatan pengelolaan dan penciptaan atmosfir wisata, peningkatan kualitas layanan, konservasi hutan, dan peningkatan daya saing kawasan wisata Kalibiru. Beberapa kebijakan yang disepakati meskipun tidak semuanya tertulis dalam bentuk dokumen, meliputi (1) kebijakan perekrutan yang terbuka untuk anggota HKm dan warga Kalibiru non anggota HKm bahkan warga dari dusun sekitar untuk menjadi pelaku wisata; (2) kebijakan keuangan meliputi pembagian hasil 
usaha kepada pemilik saham yaitu anggota HKm Mandiri Kalibiru dalam bentuk dana pengamanan hutan dan dana pengembangan wisata di HKm yang lain yang tergabung dalam Jaringan LINGKAR, serta pemberian bantuan sosial kepada masyarakat Kalibiru dan sekitarnya, dan transfer gaji karyawan melalui Bank; (3) kebijakan kedisiplinan kerja melalui penerapan jam kerja yang terkontrol dan penggunaan pakaian seragam, (4) penerapan standar operasional prosedur bagi wisatawan dalam menikmati atraksi spot foto, dan pelatihan SOP bagi karyawan; (5) Kebijakan peningkatan keamanan dan kenyamanan wisatawan melalui penyediaan kendaraan rescue, pos keamanan, dan keberadaan Tim Marshal di sepanjang jalan menuju Kalibiru, penyediaan layanan free wifi; (6) kebijakan pembangunan sarana dan fasilitas wisata yang pro konservasi dalam bentuk semi permanen; dan (7) kebijakan pelaksanaan studi banding secara berkala ke beberapa obyek wisata untuk meningkatkan daya saing pelayanan dan kebersihan serta atraksi wisatanya.

Adaptasi pada level individu terlihat pada respon individu terhadap aturan-aturan yang telah disusun dan disepakati tersebut. Secara umum masyarakat pelaku wisata taat terhadap aturan yang telah disepakati, namun responnya berbeda-beda antar individu sesuai dengan latar belakang status sosial, latar belakang ekonomi demografi dan pengalaman. Penyesuaian terhadap irama kerja merupakan kendala umum yang dialami oleh individu pelaku wisata, terutama bagi mereka yang berlatar belakang petani yang terbiasa dengan jam kerja yang bebas dan mereka yang bekerja kantoran atau di luar/di kota dengan jam kerja yang tabrakan. Penyesuaian yang dilakukan masyarakat dengan terhadap irama kerja tersebut terdiri dari 3 bentuk yaitu meninggalkan pekerjaan sebelumnya, memilih pekerjaan di wisata yang fleksibel waktunya, menyesuaikan waktu kerja di pekerjaan sebelumnya. Meskipun pengelola $\mathrm{HKm}$ dan wisata telah membuka ruang berpartisipasi bagi masyarakat Kalibiru, namun demikian tidak semua masyarakat Kalibiru dapat memanfaatkan peluang tersebut. Masyarakat yang mampu beradaptasi untuk terlibat dalam pengelolaan wisata adalah golongan (1) tokohtokoh masyarakat, (2) mereka yang memiliki pengalaman kerja di bidang jasa, (3) memiliki keterampilan dan ide-ide kreatif, (4) memiliki kemampuan finansial, dan (5) golongan masyarakat yang konsisten mendukung pengembangan wisata dari awal hingga saat ini. Tokoh-tokoh $\mathrm{HKm}$, pemuda dan masyarakat umumnya menempati posisi top manajemen baik level HKm, pengelola wisata maupun koordinator level teknis, sementara golongan 2 dan 3 umumnya menempati posisi sebagai pelaku wisata pelayanan atraksi dan administrasi. Golongan 4 umumnya membuka usaha warung dan parkir, sedangkan golongan 5 umumnya dari anggota $\mathrm{HKm}$ yang direkrut sebagai karyawan bidang keamanan, kebersihan dan pelayanan umum. Kondisi ini agak berbeda dengan temuan Setiawan, B dkk (2017) di Karimunjawa yang mana golongan masyarakat yang mampu beradaptasi ke sektor pariwisata adalah mereka yang memiliki modal, akses keuangan dan keterampilan. Secara psikologis karyawan wisata memiliki keterbatasan terkait rasa percaya diri, keterampilan serta kemampuan dalam teknis dan komunikasi. Pengurus HKm sudah melakukan bantuan pelatihan dan pemberian pakaian seragam untuk meningkatkan kapasitas dan rasa percaya diri, namun dirasa belum cukup untuk menunaikan tugas pelayanan dengan baik. Mereka merespon keterbatasan tersebut dengan bekerja secara kelompok untuk saling mengatasi kekurangan dan membangun semangat belajar bersama (learning by doing), dan belajar mandiri lewat internet.

Adaptasi masyarakat pada level rumah tangga berbeda antara satu dengan yang lainnya tergantung pada jenis keterlibatannya, anggota keluarga, dan pekerjaan sebelumnya. 
Penyesuaian pada level rumah tangga berhubungan dengan pengaturan tenaga kerja dan waktu kerja ketika musim kunjungan, pekerjaan domestik dan pertanian. Rumah tangga yang memiliki usaha warung di kawasan wisata melakukan pembagian tugas dalam rumah tangga, misalnya ibu rumah tangga bertanggung jawab terhadap warung, sementara Kepala keluarga mengelola lahan dan ternak. Ketika wisatawan ramai seperti pada week end dan hari libur anggota keluarga yang lain terlibat membantu pekerjaan di warung, bahkan terkadang menyewa orang lain untuk membantu. Pekerjaan mengurus ladang dan ternak dilakukan pada pagi dan sore hari (diluar waktu operasional wisata) atau hari lain ketika wisatawan sepi. Bagi sebagian ibu-ibu rumah tangga yang bekerja sebagai karyawan diberi waktu kerja setengah hari karena memiliki tanggung jawab domestik mengurus anak dan rumah. Jumlah keluarga yang menjadi pelaku wisata mencapai $85 \%$, melibatkan $37 \%$ perempuan dan $44 \%$ pemuda. Kondisi ini menunjukkan bahwa ekowisata Kalibiru mampu memberikan ruang akses yang luas bagi masyarakat dan mengurangi dominansi laki-laki dan orang tua dalam pembangunan.

\section{Kesimpulan}

Kasus Kalibiru memberikan pembelajaran dan penegasan kebenaran konsep ekowisata yang mampu dikembangkan oleh kelompok tani hutan melalui berbagai bentuk adapatasi. Adaptasi yang dilakukan masyarakat Kalibiru secara umum terdiri 2 jenis yaitu penyesuaian perilaku individu dan perubahan lingkungan pada level lembaga dan rumah tangga serta lingkungan fisik. Adaptasi level individu berupa perubahan sikap dan pola pikir masyarakat yang tercermin pada bentuk dukungan terhadap pengembangan ekowisata. Penyesuaian terhadap aturan main pengelolaan wisata yang diwujudkan dalam bentuk komitmen dan kepatuhan terhadap aturan yang sudah disepakati.

Adaptasi lembaga $\mathrm{HKm}$ meliputi (1) perubahan struktur organisasi dengan masuknya masyarakat non anggota $\mathrm{HKm}$ menjadi pengelola wisata dan pengurus $\mathrm{HKm}$; dan (2) penyusunan aturan main untuk mengatasi kendala pengelolaan dan penciptaan atmosfir, meningkatkan kualitas pelayanan, konservasi hutan, dan peningkatan daya saing. Wujud adaptasi pada level rumah tangga berhubungan dengan pengaturan tenaga kerja dan waktu kerja dalam menyikapi musim kunjungan, pekerjaan domestik dan pertanian. Level adaptasi ini juga menjelaskan partisipasi perempuan dalam meraih peluang kerja dan usaha wisata ditengah peran domestiknya.

Ditengah kondisi penurunan (decline) perkembangan ekowisata Kalibiru, menuntut adanya inovasi atraksi yang tidak hanya mengandalkan view dan spot foto. Pengembangan atraksi edukasi story telling $\mathrm{HKm}$ percontohan dan mendorong pengembangan potensi lokal berbasis UMKM dapat dijadikan atraksi unggulan yang tidak mudah direflikasi.

\section{Daftar Pustaka}

Aji GB, Rusida Y, Joko S, Andini DE, Tanjung S, Hasriani M. (2015). Sumbangan hutan Kemasyarakatan dan Hutan Desa terhadap Pendapatan dan Pengurangan Kemiskinan. Pusat Penelitian Kependudukan LIPI, Jakarta.

Anonim, (2017). Profil Desa Hargowilis Tahun 2016. Desa Hargowilis, Kecamatan Kokap, Kabupaten Kulonprogo.

Anonim. (2017). Profil Kelompok Tani Hutan Kemasyarakatan (KTHKm) Mandiri Kalibiru. 
Bennett, J.W. (1976). The Ecological Transition: Cultural Anthropology and Human Adaptation. Pergamon Press Inc.

Blackstock, K. (2005). A Critical Look at Community Based Tourism. Community Development Journal Vol 40. 39-49.

Butler, R.W. (1980). The Concept of A Tourist Area Cycle of Evolution: Implications for Management of Resources. Jurnal of CANADIAN GEOGRAPHER, XXIV, 1, 5-12.

Butler, R.W. (2011). Tourism Area Life Cycle. Goodfellow Publishers Ltd.

Creswell, JW. (2016). Research Design. Pustaka Pelajar, Yogyakarta.

Cruz, R.E.H, Eduardo B. B, Guillermo M.G, Erin I.J.E.L, El Colegio, F.S. (2005). Social Adaptation ecotourism in the Lacandon Forest. Annals of Tourism Research, Vol 32, No. 3, pp. 610-627.

Damanik, J. (2013). Pariwisata Indonesia. Antara peluang dan tantangan. Pustaka Pelajar, Yogyakarta.

Das, M \& Bani C. (2015). Ecotourism: A Panacea or a Predeciment. Tourism management, 14. 3-16.

Fandeli, C. (2000). Pengertian dan konsep dasar ekowisata. Dalam Pengusahaan Ekowisata. FakultasKehutanan UGM Yogyakarta.

Kaharuddin \& Satyawan P. (2016). Partisipasi masyarakat dalam pariwisata alam di hutan lindung Kalibiru Kulonprogo. Laporan DPP Fakultas Kehutanan UGM.

Kotler, P. (1986). The Element of Social Action. The American Behavioral Scientist, 14, 5. pg 691

McKercher, B. (2005). Destinations as Products? A Reflection on Butler's Life Cycle. Tourism Recreation Research, Vol. 30(3): 97-102

Mowfort, M. \& I. Munt. (1998). Tourism and Sustainability: New Tourism in Third World. London and New York.

Nasikun. (2000). Globalisasi dan Paradigm Baru Pembangunan Pariwisata Berbasis Komunitas. Dalam Pengusahaan Ekowisata. FakultasKehutanan UGM Yogyakarta.

Setiawan, B, R. Rijanta, M. Baiquni. (2017). Sustainable Tourism Development: The Adaptation and Resilience of The Rural Communities in (the tourist villages of) Karimunjawa, Central Java. Forum Geograpi, Vol 31 (2), 232-245.

Soekanto, S. (1970). Sosiologi. Suatu Pengantar. Jakarta, UI Press.

Tosun C. (2000). Limits to community participation in the tourism development process in developing countries.Tourism Management. 21, 613-633. 